\title{
ASSESSING STUDENTS' UNDERSTANDING TOWARDS CRITICAL READING AND ITS IMPACTS TOWARDS THEIR LIVES
}

\author{
Rentauli Mariah Silalahi \\ Institut Teknologi Del, Indonesia \\ (rentaulisilalahi@gmail.com)
}

Received: $25^{\text {th }}$ August 2018; Revised: $28^{\text {th }}$ October 2018; Accepted: $28^{\text {th }}$ Desember 2018

\begin{abstract}
Critical reading was not a new term for university students but the levels to how students understand it and how it could help them develop in many aspects had seldom been studied. Therefore, this study tried to explore the levels of students' understanding towards the meaning of critical reading, what possible problems could be present in the implementation, what activities could be carried out for practicing critical reading, and what benefits critical reading could bring to students' lives. This study; conducted by survey questionnaire, was focused on IT students who had just finished a Reading course and were indicated not in favor of reading. From data analysis, it was found that the IT students did not know well that critical reading required interpreting and criticizing, did not realize potential problems in implementing critical reading and was not aware that critical reading practices could help improve their academic achievements.
\end{abstract}

Keywords: critical reading; levels; understanding; interpreting; criticizing; analyzing

\begin{abstract}
ABSTRAK
Membaca kritis bukanlah sebuah istilah baru untuk mahasiswa tetapi masih jarang dilakukan penelitian terhadap tingkat pemahaman mahasiswa terhadap makna dari membaca kritis dan bagaimana dengan membaca kritis dapat membantu mahasiswa dalam banyak hal. Oleh karena itu, penelitian ini dilakukan untuk melihat tingkat pemahaman mahasiswa terhadap makna membaca kritis, terhadap masalah yang mungkin muncul ketika melakukan kegiatan membaca kritis, terhadap contoh kegiatan yang dapat mengembangkan kegiatan membaca kritis, dan terhadap manfaat dari membaca kritis terhadap kehidupan mahasiswa. Kajian ini, yang dilakukan dengan metode survei kuesioner, difokuskan kepada mahasiswa IT yang baru saja menyelesaikan mata kuliah 'Membaca' dan yang diidentifikasi kurang berminat dalam membaca. Dari kajian yang dilakukan ditemukan bahwa mahasiswa IT tersebut tidak mengetahui dengan baik bahwa membaca kritis membutuhkan kemampuan untuk menafsirkan dan mengkritik, tidak menyadari berbagai macam tantangan yang muncul dalam pelaksanaan kegiatan membaca kritis, dan tidak menyadari bahwa dengan membaca kritis mahasiswa dapat meningkatkan prestasi akademik mereka.
\end{abstract}

Kata kunci: membaca kritis; tangka; pemahama; menafsirkan; mengkritik; menganalisa

How to Cite: Silalahi , R. M. (2018). Assessing Students' Understanding Towards Critical Reading and Its Impacts Towards Their Lives. IJEE (Indonesian Journal of English Education), 5(2), 191-203. doi:10.15408/ijee.v5i2.9532.

IJEE (Indonesian Journal of English Education), 5 (2), 2018, 191-203

P-ISSN: 2356-1777, E-ISSN: 2443-0390 | DOI: http://dx.doi.org/10.15408/ijee.v5i2.9532

This is an open access article under CC-BY-SA license (https://creativecommons.org/licenses/by-sa/4.0/) 


\section{INTRODUCTION}

This study was conducted in one of the Information and Technology (IT) Universities in North Sumatera, Indonesia. Students in this university seemed to be very rare to read books or make reading as a habit while as university students they should have undeniably made reading as a mandatory activity because lack of reading might result in low academic performance (Ahmadi \& Bajelani, 2012, Spector-Cohen et al., 2001). In many occasions, students preferred playing games with their gadgets; mostly with mobile phones to reading books. The phenomenon was even getting worse when students who repeated courses as the result of failing the courses in the regular semester still preferred playing games to reading books even in the test term. There had been many approaches done by the university to tell students stop playing games and start reading and other useful activities, yet the notice seemed to be ignored continuously. That very critical issue pushed the university to make a new regulation which stated that students found playing games on their gadgets during office hours would be fined for a certain amount of money. Yet, it was still seemed to be ignored because after the new regulation was announced, there were still some students who were caught playing games on their mobile phones during office hours in their classrooms.
The other significant problem was the students' very limited ability to argue critically towards a text. There were some occasions where students were tested for their ability to do critical reading and to respond critically towards what they had read, but most of the time students seemed to be silent and could not give their genuine critical ideas and comments. It would be an indication that students had not been engaged in reading in their academic life. There were also times when students were not able to write critically towards what they had read and had tendency to simply copy and paste what they read (the author's exact sentences) to the paper for writing assignments. They were not able to connect the information they read to what they had known before about the text and to what they personally felt about the text. It seemed that being critical readers was still far from the students' main menu. Therefore, this study focused on students in expectation to find their levels of understanding towards critical reading and its impacts towards the students' lives. This would be the very basic study that would initiate further researches for in-depth analysis towards all possible factors that influenced the levels of students' understanding.

In order to practice critical reading, students should firstly be motivated to have reading as a habit. In reality, as observed in majority schools and universities in North Sumatera, Indonesia, it was very hard to find 
students who were fond of reading; students were rarely seen to hold and read a book if not for a test. It was also a rare occasion to see students stayed in the library and read books if not for assignments. Therefore, the main problem to deal with is actually making reading as a habit. But implementing critical reading may also become the solution to motivate students to have reading as a habit. Overall, it can be quite inseparable and interrelated (Zigo, D, Moore, 2004). Reading critically is mostly needed in university level though it may also be possible to be trained from early years like primary schools because a habit acquired from an early age will most probably remain and become better afterwards. Looking at the Indonesian 2013 curriculum, it seemed that the critical reading ability had already been trained from primary schools (Prihantoro, 2015) but it seemed that students had not been well impacted by the curriculum.

Reading meant understanding, interpreting, analyzing, and criticizing texts (Oliveras, Márquez, \& Sanmartí, 2013, p. 887). However, a reader's ability to understand, interpret, analyze and criticize a text depended on the reader's knowledge of the given text and the context and culture embedded in the reader's knowledge (Pitchers \& Soden, 2000 cited in Oliveras et al., 2013). It was very obvious that a reader's critical reading skill was inseparable from his/her personal experiences and cultures and that the word 'reading' itself carried along the task for being 'critical' in it.

On her paper, Lee (2016) boldly claimed that being critical was being able to expose one's opinion freely but still with ability to connect the personal ideas to some related facts presented in the text. Critical reading was not only about reading passages, but it could also be done for visual text. When reading any text either a non-visual or visual text, someone's personal evaluation towards the text might be influenced by his/her background knowledge related to the text. It would open up a window of differences between one reader to the others because the subjective point of views of one reader was different one to another. The following diagram tried to map the definitions of critical reading as discussed above.

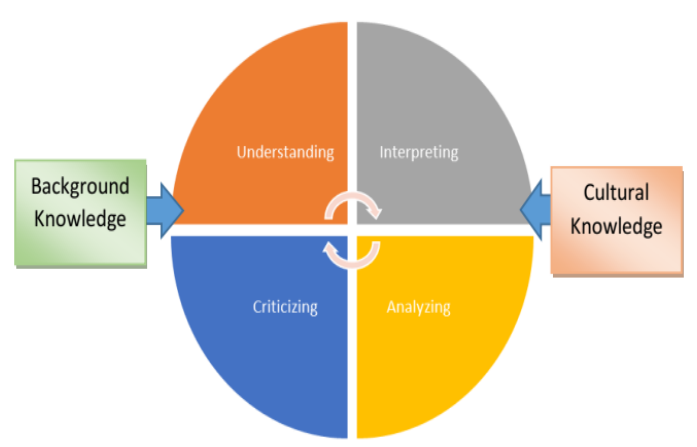

Diagram 1. What Critical Reading

There were many ways for implementing critical reading in classrooms yet the essential norms should be well maintained. The norms referred to the meaning of the critical reading itself that it should involve 
active interaction between the reader and the text in which the reader should apply the critical skills like interpreting and analyzing towards the text. Davies (1995 cited in Tomitch, 2008) mentioned that critical reading activities should meet these criteria: the texts used were authentic materials (texts that were not purposely written for classroom use; such texts could be found easily in everyday life), the reading task should contextualize reading (the reader should see the text from different perspectives both from the author and reader's social life), text should be approached with some ready frameworks in the reader's mind (readers might have some personal perspectives towards the text), readers should be given space to do analytical approach towards the text (to acquire more coherent and accurate meaning of the text), text should be able to make readers interact with the text (readers should bring into the text his/her previous related knowledge and background), and text should be able to make readers interact with classmates (changing and discussing opinions about the text).

Tomitch (2008) further suggested the use of pre-reading task that motivated students to talk about the text without reading the complete text like reading the title only. The process of a critical reading activity according to Tomitch would involve pre-reading activities in which the pre-reading task would enable students to link their background knowledge and experiences to what they read, to freely give opinion and to raise questions. The pre-reading task would certainly be followed by main task which meant that after all assumptions were made, the students were then invited to look at the complete reading text thoroughly. Afterwards, the students compared the assumptions they made before reading and their understanding after reading the text. By the end, the students were able to analyze the author's purposes in writing the text and gave final opinions that could be just the same or probably quite different from the author's.

Another author that suggested some comprehensive critical reading activities came from Albeckay (2014). The study skills Albeckay (2014, p. 177) suggested that could become recommendations to other EFL classes were 'distinguishing facts from opinions, identifying the author's purpose and tone, making inferences, making evaluation, and analyzing the text.' Meanwhile, Albeckay (2014) structured the class meetings into three sessions from teacher giving a complete clear instruction of the theoretical analysis of what was learnt and making the students think aloud then grouping students to help each other for the reading assignments and finally requiring each student to work individually to produce his/her own thought for the remaining reading assignment. 
The other researcher that also had good ideas on how to conduct critical reading activities were Duran and Yalçintaş (Duran \& Yalçintaş, 2015). Some of their recommended activities that might be doable to other EFL classes were like questioning the knowledge offered from the text, sorting out the main issues raised in the text, finding out the similarities or differences between the author's opinions and the reader, analyzing text that included scrutinizing facts and imaginary thoughts, defining the objective and subjective goals of the text, and determining the author's purpose in writing the text (Duran \& Yalçintaş, 2015).

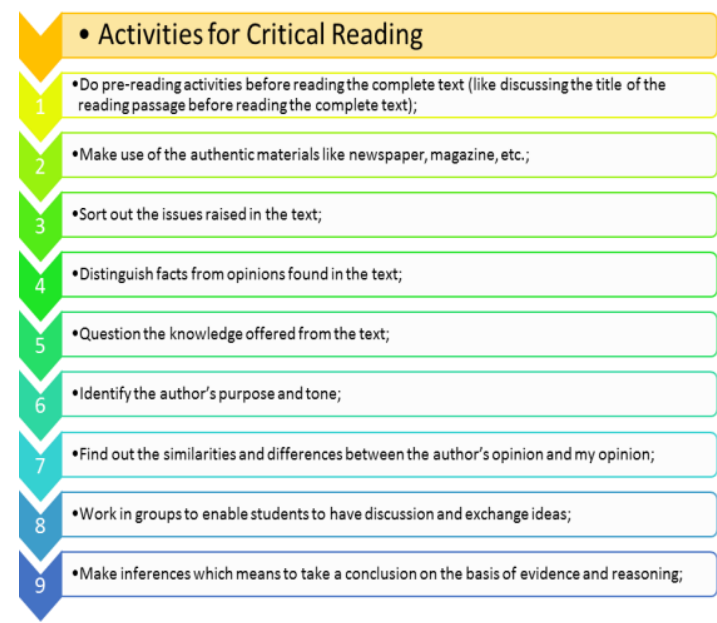

Diagram 2. Some recommended activities for critical reading practices

The three authors'
recommenddations for critical reading activities were motivating and doable, yet there were some that were overlapping from one author to the others. Therefore, for this study, the recommendations were then mapped into more logical and efficient activities but still maintained its originality and did not lose its meaning as shown on the following diagram 2 .

Looking more critically on the three authors' genuine opinions on how to carry on critical reading activities that had been mapped for more clarity and avoiding overlapping, it seemed that the critical reading activities supported the theory of learning as content which meant that 'learning was seen as the behavior exhibited as a result of the learning' (Jarvis, P, Holford, J., Griffin, 1999 , p. 9). In the end, the students who were trained to do critical reading would have greater possibility to be 'responsible and autonomous learner' (Ur, 2001, p. 3). Students who were responsible and autonomous meant they consciously knew that they should be active and do some efforts to understand their lessons, work with their teachers and peers for more understanding, be responsible for their mistakes and used their free time wisely to learn more and work on their mistakes and weaknesses (Ur, 2001).

Indonesia seemed to still work on how to implement the 2013 curriculum appropriately in all levels of education as there were some limitations and weaknesses like limited access to facilities, teachers' lack of abilities, and time constraints for completing the syllabuses on time (Ilma \& Pratama, 2015). These might also be possible problems in Indonesian reading classrooms in trying to apply the 
recommended activities for critical reading. Actually, these kinds of problems might not be specific to Indonesian context but to the whole world because other researchers like Duran \& Yalçintaş (2015) pointed some problems like time limit for classroom meeting, too much activities, and students' limited ability to argue critically as the main reasons that hindered the accomplishment of the target for critical reading practices in Primary schools in Turkey. Yet, with more time and longer period of practices, those visible problems might be minimalized if not omitted.

However, it should be well understood that it was still very difficult to apply the critical reading test into classrooms that targeted students to pass a certain test like TOEFL and IELTS. These two tests could be classified as having closed ended reading test that did not give any chance for the test takers to freely analyze and give comments about the reading texts. But testing was only for specific occasions and life was a different story. In real life, people can argue, repeat, evaluate, analyze, and negotiate meaning, therefore critical reading is more to life skill than to rigid academic tests. The following diagram was provided to clearly point out the possible problems as discussed before:

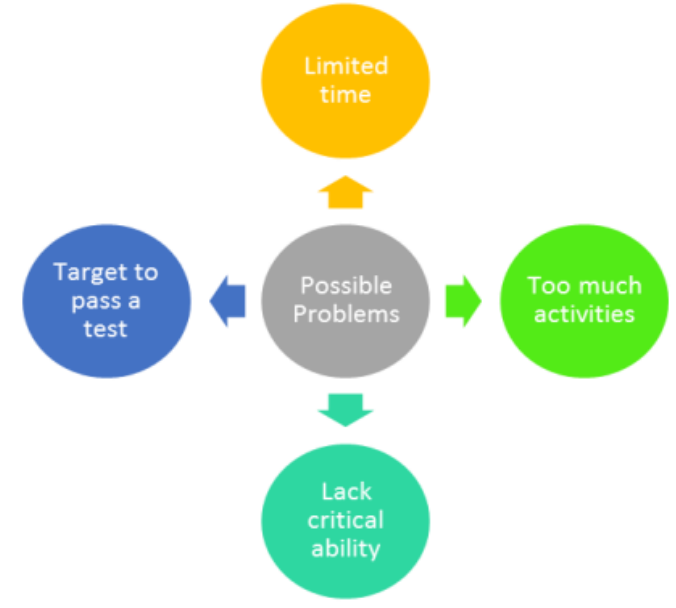

Diagram 3. Possible problems in critical reading classrooms

Even though Akin (Akın, Koray, \& Tavukçu, 2015) did not elaborate the real practices and procedures conducted in the critical reading classrooms, they mentioned some positive impacts resulted from the process. Besides getting a higher academic score, the benefits were also about getting students motivated to read for comprehension and encouraged to develop communication with other students which might help them start making meaning from their reading texts because they commented and evaluated the text by giving their personal opinions.

Lee (2016) emphasized how the critical reading was not only a classroom demand but also a long life lasting requirement. When students got used to reading critically, they would most probably be engaged in whatever they read. Being engaged was the desired outcome for students because that would help students be able to cope 
with their lives intelligently as an individual and social person and it was in congruence with what (Gambrell, 1996) mentioned that engaged readers would tend to be more motivated, become knowledgeable and socially interactive and be strategic in terms of balancing skill and will to read. As a result, a reader would be able to get the meaning of the text and to construct new knowledge that might be useful for his/her life (Oliveras et al., 2013). Those possible positive impacts on students' lives were drawn on the following diagram 4 .

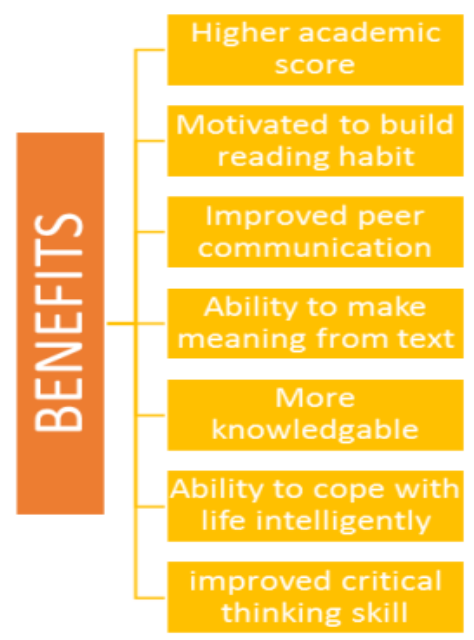

Diagram 4. Possible benefits from critical reading practices

Having stated the related references, it is important to note that this study only assesses students' understanding towards the theory and practices involved in critical reading and the results of this study are expected to give contributions to the teachers to take necessary actions based on the findings. This study research questions are formulated as follows: 1) What is the IT students' levels of understanding towards critical reading?; 2) What is the IT students' levels of understanding towards the kinds of activities that could help implement critical reading?; 3) What is the IT students' levels of understanding towards the possible problems that might occur in doing critical reading in classrooms? And; 4) What is the IT students' levels of understanding towards the benefits of doing critical reading for their lives?.

\section{METHOD}

This study was a descriptive type of research since the study tried to describe the students' understanding without aiming at changing it although the study eventually tried to 'provoke changes in the education world' (Coe, R., Waring, M., Hedges, L. V., Arthur, 2017) and the data collected were through survey questionnaire.

The focus of the research was a group of IT students, aged between nineteen to twenty one years old, who had just completed a course in Reading. There were initially a total of 60 students who had finished the Reading course and all were invited to participate in the questionnaire, yet only 46 students returned the questionnaire within the 2 weeks given time. Although the student participants were heterogeneous; male and female, the study did not facilitate findings based 
on gender in order to fit into the research purposes.

The tool used for data collection was survey questionnaire which was designed using a five point Likert scale with designations from strongly agree to strongly disagree. The respondents were asked to rate the items to what they believed to be true and their perspectives would be well expressed by the degree of their agreement. By using the Likert scale survey questionnaire, the author would be able to define the tendency of the students' perspectives either towards negative or positive impressions because the greater the score, the more positive the attitude and vice versa (Wiersma, 1969). The students' responses were considered positive only when they chose strongly agree to agree.

Data collection was conducted using technology because the time and place constraints in conducting this study. Although Gorard (2006) claimed that this method of collecting data was not actually a very good method of collecting data for gathering opinions, attitudes and explanations because it closed the possibility to collect 'in-depth personal responses' (Burton, D., Bartlett, 2009), the constraints made it the only possible way. The use of technology in this term meant the 'technology based' (Gorard, 2006) method in which the questionnaire was sent by 'computer-delivered' tool (Coe, R., Waring, M., Hedges, L. V., Arthur, 2017); the google tool for survey questionnaire.
This data collection method which promised anonymity was the most effective and efficient way compared to other research methods and through this method, the questions could be written for specific purposes (Opie, 2004 cited in Burton, D., Bartlett, 2009).

There were four sections in the questionnaire that invited students to give their opinions about critical reading. The first section was about students' understanding about the meaning of critical reading, and the second section was about students' perspectives on what activities could contribute to implementing critical reading. Move on to the third section, it required students to give opinions on what possible problems might occur in the process of implementing critical reading, and finally the fourth section was trying to know the students' perspectives on the positive impacts of conducting critical reading activities. All items presented on the questionnaire had been modified and molded by taking into considerations all literatures quoted for this study.

\section{FINDINGS AND DISCUSSION}

The survey questionnaire was finally collected from all respondents in two weeks after the request email consisting information about the study, consent form and questionnaire was sent to all respondents. After that, the data collected were analyzed to see the percentages of students' agreement to 
each item and category. The analysis involved 'describing and explaining what the results showed in relation to the respective research questions' (Burton, D., Bartlett, 2009, p. 80) although it was only by seeing the numerical numbers. The analysis was carried out following the questions already constructed in the beginning of this study as it would directly answer the research questions appropriately and the percentages shown on the table were only for the 'strongly agree' and 'agree' columns because it would better express the tendency for positive agreement.

Table 1. Students' levels of agreement towards the meaning of critical reading

\begin{tabular}{llllll}
\hline $\begin{array}{l}\text { Critical reading } \\
\text { means }\end{array}$ & Strongly agree & Agree & $\begin{array}{l}\text { Neither Agree or } \\
\text { Disagree }\end{array}$ & $\begin{array}{l}\text { Disagree } \\
\begin{array}{l}\text { Strongly } \\
\text { disagree }\end{array}\end{array}$ \\
\hline $\begin{array}{l}\text { understanding } \\
\text { text; }\end{array}$ & $5(10.9 \%)$ & $25(54.4 \%)$ & 15 & 1 & 0 \\
\hline interpreting text; & $2(4.3 \%)$ & $22(47.8 \%)$ & 23 & 0 & 0 \\
\hline analyzing text; & $9(19.6 \%)$ & $26(56.5 \%)$ & 12 & 0 & 0 \\
\hline criticizing text; & $2(4.4 \%)$ & $20(43.5 \%)$ & 24 & 1 & 0 \\
\hline
\end{tabular}

Table 2. Students' levels of agreement towards activities that could help improve critical reading

\begin{tabular}{|c|c|c|c|c|c|}
\hline $\begin{array}{l}\text { Activities that contributed to implementing } \\
\text { critical reading }\end{array}$ & $\begin{array}{l}\text { Strongly } \\
\text { agree }\end{array}$ & Agree & $\begin{array}{l}\text { Neither Agree } \\
\text { or Disagree }\end{array}$ & Disagree & $\begin{array}{l}\text { Strongly } \\
\text { disagree }\end{array}$ \\
\hline $\begin{array}{l}\text { Do pre-reading activities before reading the } \\
\text { complete text (like discussing the title of the } \\
\text { reading passage before reading the complete } \\
\text { text); }\end{array}$ & $3(6.5 \%)$ & $20(43.5 \%)$ & 23 & 0 & 0 \\
\hline $\begin{array}{l}\text { Make use of the authentic materials like } \\
\text { newspaper, magazine, etc; }\end{array}$ & $2(4.3 \%)$ & $29(63 \%)$ & 14 & 1 & 0 \\
\hline Sort out the issues raised in the text; & $3(6.5 \%)$ & $25(54.4 \%)$ & 18 & 0 & 0 \\
\hline $\begin{array}{l}\text { Distinguish facts from opinions found in the } \\
\text { text; }\end{array}$ & $3(6.5 \%)$ & $26(56.5 \%)$ & 17 & 0 & 0 \\
\hline Question the knowledge offered from the text; & $3(6.5 \%)$ & $25(54.4 \%)$ & 19 & 1 & 0 \\
\hline Identify the author's purpose and tone; & $2(4.3 \%)$ & $30(65.2 \%)$ & 15 & 1 & 0 \\
\hline $\begin{array}{l}\text { Find out the similarities and differences } \\
\text { between the author's opinion and my opinion; }\end{array}$ & $3(6.5 \%)$ & $21(45.7 \%)$ & 20 & 2 & 0 \\
\hline $\begin{array}{l}\text { Work in groups to enable students to have } \\
\text { discussion and exchange ideas; }\end{array}$ & $\begin{array}{l}11 \\
23.9 \%)\end{array}$ & $24(52.1 \%)$ & 11 & 0 & 0 \\
\hline $\begin{array}{l}\text { Make inferences which means to take a } \\
\text { conclusion on the basis of evidence and } \\
\text { reasoning; }\end{array}$ & $2(4.3 \%)$ & $27(58.7 \%)$ & 16 & 1 & 0 \\
\hline
\end{tabular}

Table 3. Students' levels of agreement towards problems that might be encountered while practicing critical reading activities

\begin{tabular}{llllll}
\hline $\begin{array}{l}\text { Possible problems encountered when } \\
\text { implementing critical reading }\end{array}$ & $\begin{array}{l}\text { Strongly } \\
\text { agree }\end{array}$ & Agree & $\begin{array}{l}\text { Neither } \\
\text { Agree } \\
\text { Disagree }\end{array}$ & or & $\begin{array}{l}\text { Disagree } \\
\text { disagree }\end{array}$ \\
\hline Limited time; & $4(8.7 \%)$ & $22(47.8 \%)$ & 19 & 1 & 0 \\
\hline Too much activities; & $1(2.2 \%)$ & $15(36.6 \%)$ & 23 & 7 & 0 \\
\hline Lack critical ability; & $3(6.5 \%)$ & $11(23.9 \%)$ & 25 & 6 & 1 \\
\hline Target to pass a test; & $1(2.2 \%)$ & $18(39.1 \%)$ & 22 & 5 & 1 \\
\hline
\end{tabular}


Table 4. Students' levels of agreement towards the positive impacts of critical reading

\begin{tabular}{|c|c|c|c|c|c|}
\hline $\begin{array}{l}\text { Possible impacts of conducting } \\
\text { critical reading activities }\end{array}$ & Strongly agree & Agree & $\begin{array}{l}\text { Neither } \\
\text { Agree or } \\
\text { Disagree } \\
\end{array}$ & Disagree & $\begin{array}{l}\text { Strongly } \\
\text { disagree }\end{array}$ \\
\hline Higher academic score; & $3(6.5 \%)$ & $21(52.2 \%)$ & 21 & 1 & 0 \\
\hline $\begin{array}{l}\text { Motivated to build reading } \\
\text { habit; }\end{array}$ & $5(10.9 \%)$ & $23(60.9 \%)$ & 17 & 1 & 0 \\
\hline Improved peer communication; & $3(6.5 \%)$ & $32(76 \%)$ & 11 & 0 & 0 \\
\hline $\begin{array}{l}\text { Ability to make meaning from } \\
\text { text; }\end{array}$ & $4(8.7 \%)$ & $27(67.4 \%)$ & 15 & 0 & 0 \\
\hline More knowledgeable; & $7(15.2 \%)$ & $31(82.6 \%)$ & 9 & 0 & 0 \\
\hline $\begin{array}{l}\text { Ability to cope with life } \\
\text { intelligently; }\end{array}$ & $3(6.5 \%)$ & $26(63 \%)$ & 17 & 0 & 0 \\
\hline Improved critical thinking skill; & $10(21.7 \%)$ & $21(67.4 \%)$ & 16 & 0 & 0 \\
\hline
\end{tabular}

\section{Students' understanding about the meaning of critical reading}

It was obviously shown from table 1. The data that not all students understood the meaning of critical reading well (Oliveras, Márquez, \& Sanmartí, 2013, p. 887) because half of the students did not know that reading critically would involve interpreting and criticizing text. Meanwhile, it was a good indication that most students at least knew that reading critically meant analyzing test as $76 \%$ of the students gave agreement to that statement. The significant number of students giving a neutral answer indicated that they were actually not realizing and probably never gave a thought of the importance of critical reading in their reading practices.

\section{Students' understanding on what activities can contribute to implementing critical reading}

These findings interestingly shown from table 2, that more than half of the students understood that those activities listed were good examples that could be done in order to evoke their critical thinking skill (Tomitch, 2008) as sixty to seventy six percent of the students agreed to seven kinds of activities mentioned. There were possibilities that students had done such activities. However, half of the students did not understand that pre-reading tasks and finding out differences or similarities between readers and author's views towards a text were good examples of activities to provoke critical reading.

\section{Students' understanding on possible problems that might be encountered in doing critical reading in classrooms}

These findings clearly indicated shown from table 3 , that there was a big number of students who did not realize the problems that could occur while implementing critical reading in classrooms (Ilma \& Pratama, 2015, Duran \& Yalçintaş, 2015) as the number of students who disagreed were more compared to the previous findings and there were two students who strongly disagreed to the possible troubles that 
might happen in carrying out critical reading activities. The number of students who agreed to the given statements was only thirty to fifty six percent and that was not a reliable number for a good level of understanding. Again, there was a possibility that students had limited experiences on practicing critical reading.

\section{Students' perspectives on the positive impacts of conducting critical reading activities}

These findings interestingly indicated shown from table 4, that more students were aware of the benefits they might get if they practiced reading critically (Lee, 2016, Akın et al., 2015). Seventy six to eighty two percent of the students knew that critical reading practices would help them improve communication among peer students and make them more knowledgeable while sixty to sixty seven percent of the students agreed that critical reading could help them make reading as a habit, make meaning from text, improve critical reading skill, and improve ability to cope with life intelligently. On the other hand, it was also an interesting finding to know that half of the students did not understand that critical reading could help them achieve higher on academic performances.

\section{CONCLUSION AND SUGGESTION}

The students' levels of understanding towards critical reading was very poor because they were not aware of the importance of criticizing and interpreting when they practiced critical reading. It was still very likely that students would take for granted whatever they read. The other weaknesses of the students were their very limited understanding towards possible problems that might happen while doing critical reading activities and their unawareness that by doing critical reading could help improve their academic achievements. Looking at the levels of students' understanding towards critical reading, it was quite possible that they were still unable to be responsible learners and have self-encouragement to be autonomous learners (Ur, 2001) which should have given precious impacts on their academic achievement.

There could be many causes contributed to the students' lack of understanding about critical reading and the benefits of practicing critical reading to their lives; academically or non-academically. Therefore it would be a good idea to do a further research to find out what exactly happened in the course delivery such as whether students were clearly taught and trained to do critical reading, whether they were encouraged to read as often as possible, whether the students might refuse to do critical reading for various reasons like having no intrinsic and 
extrinsic motivation (Gardner, 1985) whether they had too much demand from other major courses in the university that made them give the least priority to learn English courses as they were not major courses, whether the teachers got difficulty understanding critical reading itself, and whether the teachers had different purposes in delivering the course that had do to with the course curriculum.

\section{REFERENCES}

Akın, F., Koray, Ö., \& Tavukçu, K. (2015). How Effective is Critical Reading in the Understanding of Scientific Texts? Procedia - Social and Behavioral Sciences, 174, 2444-2451.

https://doi.org/10.1016/j.sbspro. 2015.01.915

Albeckay, E. M. (2014). Developing Reading Skills through Critical Reading Programme amongst Undergraduate EFL Students in Libya. Procedia - Social and Behavioral Sciences, 123, 175-181. https://doi.org/10.1016/j.sbspro. 2014.01.1412

Burton, D., Bartlett, S. (2009). Key Issues for Education Researchers. London: SAGE Publications Ltd.

Coe, R., Waring, M., Hedges, L. V., Arthur, J. (2017). Research Methods $\mathcal{E}$ Methodologies in Education. London: SAGE Publications Ltd.
Duran, E., \& Yalçintaş, E. (2015). Review of the Critical Reading Education in the Primary Schools1. Procedia Social and Behavioral Sciences, 174, 1560-1566.

https://doi.org/10.1016/j.sbspro. 2015.01.788

Gambrell, Li. B. (1996). Creating Classroom Cultures that Foster Reading Motivation. The Reading Teacher, 50(1), 14-25.

Gardner, R. C. (1985). Social psychology and second language learning: the role of attitudes and motivation. London: Edward Arnold.

Gorard, S. (2006). Quantitative Methods in Educational Research: the role of numbers made easy. London: MPG Books Ltd.

Ilma, Z., \& Pratama, R. K. (2015). Transformation in Indonesian Language Curriculum: Pros and Cons between KTSP 2006 and Curriculum 2013 in Indonesia. Proceedings of Internationl Conference on Trends in Economics. Humanities and Management, 146-148.

Jarvis, P, Holford, J., Griffin, C. (1999). The theory and practice of learning. London: Kogan Page Limited.

Lee, C. (2016). A Habermasian Approach to Critical Reading. Educational Philosophy and Theory, 48(6), 579-588. https://doi.org/10.1080/0013185 7.2015.1058218 
Oliveras, B., Márquez, C., \& Sanmartí, N. Tomitch, L. M. B. (2008). Designing (2013). The Use of Newspaper Articles as a Tool to Develop Critical Thinking in Science Classes. International Journal of Science Education, 35(6), 885-905. https://doi.org/10.1080/0950069 3.2011 .586736

Prihantoro, C. R. (2015). The perspective of curriculum in Indonesia on environmental education. International Journal of Research Studies in Education, 4(1), 77-83. https://doi.org/10.5861/ijrse.201 4.915

Spector-Cohen, E., Kirschner, M., \& Wexler, C. (2001). Designing EAP Reading Tasks to Foster Critical Thinking. Ilha Do Desterro - A Journal of English Language, Literatures in English and Cultural Studies, (38), 83-90.

Ur, P. (2001). Learner Autonomy. Cambridge: Cambridge University Press.

Wiersma, W. (1969). Research Methods in Education: an Introduction. Toronto: Allyn and Bacon, Inc.

Zigo, D, Moore, M. T. (2004). Science Fiction: Serious Reading, Critical Reading. English Journal, 94(2), 85-90. reading courses at the university level. English for Specific Purposes, 20(4), 367-386. https://doi.org/10.1016/S0889-49 06(00)00019-3 